\title{
Evidence for a local role of inhibin or inhibin $\alpha$ subunits in compensatory ovarian hypertrophy
}

\author{
B. F. King ${ }^{1}$, J. H. Britt ${ }^{1 *}$, K. L. Esbenshade ${ }^{I}$, W. L. Flowers ${ }^{1}$ and \\ J. J. Ireland ${ }^{2}$ \\ ${ }^{1}$ Department of Animal Science, North Carolina State University, Raleigh 27695-7621 NC, USA; and \\ ${ }^{2}$ Molecular Reproductive Endocrinology Laboratory, Department of Animal Science, Michigan State \\ University, East Lansing 48824-1225, MI, USA
}

\begin{abstract}
The aim of this study was to determine whether immunoneutralization of inhibin altered compensatory ovarian hypertrophy. Crossbred postpubertal gilts actively immunized with a synthetic bovine inhibin peptide fragment (bINH) conjugated to human alpha globulins (HAG, $n=4$ gilts) or HAG alone (control; $n=5$ ) were unilaterally ovariectomized at mid-cycle. After unilateral ovariectomy, the remaining ovary was removed between day 8 and day 12 of the subsequent oestrous cycle. The number of corpora lutea per ovary was determined at each ovariectomy. Blood samples were collected at frequent intervals beginning $1 \mathrm{~h}$ before and continuing until the first oestrus after unilateral ovariectomy, and serum concentrations of FSH, LH, progesterone and oestradiol were determined. Inhibin antibody titres were estimated from the percentage of ${ }^{125}$ I-labelled bINH bound to serum diluted 1:4000. At unilateral ovariectomy, the number of corpora lutea per ovary was similar for bINH:HAG-immunized and control gilts $(8.6 \pm 0.7$ versus $7.6 \pm 0.6)$. During the next oestrous cycle after unilateral ovariectomy, the number of corpora lutea on each remaining ovary had doubled $(P<0.05)$ in controls compared with the number of corpora lutea per ovary in the previous cycle. In contrast, the number of corpora lutea remained unchanged in bINH:HAG-immunized gilts. Titre of anti-inhibin antibodies in bINH:HAG-immunized gilts was $9 \pm 1 \%$ at unilateral ovariectomy compared with $0 \%$ for controls. Alterations in serum concentrations of hormones after unilateral ovariectomy did not differ between treatment groups. Compensatory ovarian hypertrophy was blocked after unilateral ovariectomy in immunized gilts independent of alterations in serum hormones, duration of oestrous cycle, or normal ovulation rate per ovary. Thus, it is concluded that inhibin or inhibin $\alpha$ subunits are positive local stimulators of compensatory ovarian hypertrophy in postpubertal gilts.
\end{abstract}

\section{Introduction}

After unilateral ovariectomy of litter-bearing species, the remaining ovary undergoes compensatory ovarian hypertrophy resulting in approximately the same number of ova being ovulated (Hermreck and Greenwald, 1964; Short et al., 1969; Butcher, 1977) and a similar litter size (Hunter, 1787) compared with both ovaries before unilateral ovariectomy. Although mechanisms regulating compensatory ovarian hypertrophy are not precisely defined, a transient increase in FSH concentrations (Welshen et al., 1978; Redmer et al., 1984, 1985; Coleman et al., 1984; Cox et al., 1987; Ackland et al., 1990) coincident with a transient decrease in inhibin bio- and immuno-activities in plasma (Redmer et al., 1986; Ackland et al., 1990) occurs within 2 days of unilateral ovariectomy compared with sham-operated

*Reprint requests: College of Veterinary Medicine, NC State University, 4700 Hillsborough St., Raleigh NC 27606.

Received 27 January 1995. controls. These results imply that unilateral ovariectomy temporarily reduces the negative feedback effects of inhibin resulting in a transient increase in FSH which, in turn, leads, via an unknown mechanism, to a doubling of the ovulation rate in the remaining ovary. The present study used the unilateral ovariectomy model to investigate the role of inhibin in follicular growth. The objective of our study was to test whether immunoneutralization of inhibin altered compensatory ovarian hypertrophy after unilateral ovariectomy of postpubertal gilts.

\section{Materials and Methods}

\section{Animals}

A randomly selected subset of five gilts actively immunized against inhibin and five control gilts from a previous study (King et al., 1993) were used in the present study as explained 
below. Gilts were housed in a curtain-sided building in individual stalls $(0.8 \mathrm{~m} \times 1.8 \mathrm{~m})$ and fed $1.8-2.7 \mathrm{~kg} \mathrm{day}^{-1}$ of a $14 \%$ crude protein corn/soybean diet fortified with vitamins and minerals to meet National Research Council recommendations (NRC, 1988). All surgical procedures and animal care were approved by the Animal Care and Use Committee at North Carolina State University.

\section{Immunization}

Details of the immunization procedure are described by King et al. (1993). Briefly, each gilt received a primary immunization of $\alpha_{c}{ }^{1-26} \mathrm{Gly}$-Tyr bovine inhibin peptide (bINH) conjugated to human alpha globulins (HAG; Sigma, St Louis, MO) or HAG mixed in Freund's complete adjuvant (CalbiochemNovbiochem Corp., San Diego, CA) during the second postpubertal oestrous cycle (week 0 ) followed by two boosters in Freund's incomplete adjuvant at weeks 8 and 12 . Gilts immunized against bINH:HAG received unconjugated bINH in Freund's incomplete adjuvant at week 16 to stimulate antibody titres, whereas controls received adjuvant only.

\section{Experimental protocol}

On day 10 of the first oestrous cycle after week 19, which was approximately 4 weeks after the last booster, gilts were unilaterally ovariectomized. At unilateral ovariectomy, analgesia was induced with a $1: 1(\mathrm{v}: \mathrm{v})$ mixture (i.v.) of xylazine (Rompum; Miles Laboratories, Shawnee, KS; $2.2 \mathrm{mg} \mathrm{kg}^{-1}$ body mass) and ketamine hydrochloride (Ketaset; Bristol Laboratories, Syracuse, NY; $2.2 \mathrm{mg} \mathrm{kg}^{-1}$ body mass). Halothane (Halocarbons Laboratories, Hackensack, NJ), oxygen and nitrous oxide were used to maintain a surgical plane of anaesthesia. Ovulation rate was estimated by counting the number of corpora lutea. Cystic follicles $(>10 \mathrm{~mm}$ ) were observed in one bINH:HAG immunized gilt at unilateral ovariectomy; this gilt was removed from the study. After unilateral ovariectomy, gilts were observed for $30 \mathrm{~min}$ each day in the continuous presence of a boar until detection of the subsequent oestrus. To determine whether compensatory ovarian hypertrophy had occurred, the remaining ovary was removed by mid-ventral laparotomy between day 8 and day 12 of the first oestrous cycle after unilateral ovariectomy and the number of corpora lutea per ovary after unilateral ovariectomy was compared with the number per ovary before unilateral ovariectomy.

\section{Blood sampling, antibody titres and radioimmunoassays}

On day 9 of the first oestrous cycle after week 19, a catheter was installed into the anterior vena cava of each gilt (Britt et al., 1991). To maintain patency, catheters were flushed with $0.12 \mathrm{~mol}$ sodium citrate $\mathrm{l}^{-1}$ after each sample was collected. Blood was sampled $\mathrm{Ih}$ before unilateral ovariectomy, every $2 \mathrm{~h}$ for $24 \mathrm{~h}$ after unilateral ovariectomy, and then every $6 \mathrm{~h}$ until oestrus. Blood samples were clotted overnight at $4^{\circ} \mathrm{C}$, and serum was collected by decanting the supernatant after centrifugation at $1700 \mathrm{~g}$ for $30 \mathrm{~min}$. Serum was stored at $-20^{\circ} \mathrm{C}$ until assayed for $\mathrm{LH}, \mathrm{FSH}$, progesterone and oestradiol.

Antibody titres were determined at week 17 ( 7 days after the last booster) and at week 23 when unilateral ovariectomy was carried out by incubating serial dilutions of serum with 20000 c.p.m. of the ${ }^{125}$ I-labelled bINH at $5^{\circ} \mathrm{C}$ (Martin et al., 1991a, b; King et al., 1993). Titres were expressed as percentage of ${ }^{125} \mathrm{I}$-labelled bINH bound at a 1:4000 dilution of serum.

Previously validated radioimmunoassays were used to quantify serum concentrations of oestradiol (Howard and Britt, 1990), progesterone (Stevenson et al., 1981), LH (Stevenson et al., 1981; Armstrong and Britt, 1987) and FSH (Guthrie and Bolt, 1983; Esbenshade and Britt, 1985). Inter- and intra-assay coefficients of variation ranged from $9 \%$ to $14 \%$ for each assay. For statistical analysis, FSH values below assay sensitivity were assigned a value equal to the limit of sensitivity of the assay.

\section{Statistical analyses}

All analyses were conducted using general linear models (SAS, 1985). Data for concentrations of LH, FSH, oestradiol and progesterone were subjected to split-plot ANOVA for repeated measures (Gill and Hafs, 1971). The model included treatment, gilt within treatment, time and time $\times$ treatment interaction. Main effect of treatment was tested using the gilt within treatment mean square as error term. Data were analysed as time (h) from unilateral ovariectomy and time (h) from day of oestrus because animals had a variable number of days between unilateral ovariectomy and oestrus. Data for duration of oestrous cycle were analysed by one-way ANOVA, whereas data for number of corpora lutea per ovary before and after unilateral ovariectomy were analysed by two-way ANOVA.

\section{Results}

\section{Compensatory ovarian hypertrophy}

After unilateral ovariectomy, the mean ( \pm SEM) number of corpora lutea per ovary increased $(P<0.01)$ over twofold in controls (7.6 \pm 0.6 to $16.2 \pm 1.2$ ) but remained unchanged $(P>0.10)$ in gilts immunized against bINH:HAG $(8.6 \pm 0.7$ versus $10 \pm 2.1$ ) compared with the number of corpora lutea per ovary at unilateral ovariectomy. Further statistical comparisons indicated that the number of corpora lutea per ovary for bINH:HAG-immunized gilts and controls was not different $(P>0.10)$ at unilateral ovariectomy, whereas the number of corpora lutea after unilateral ovariectomy was greater $(P<0.05)$ in controls compared with bINH-immunized gilts.

\section{Duration of oestrous cycle}

Mean ( \pm SEM) duration of the oestrous cycle during which unilateral ovariectomy was performed did not differ between treatment groups $(21.3 \pm 1.6$ for bINH:HAG versus $19.0 \pm 0.9$ days for control gilts).

\section{Hormone profiles}

Serum concentrations of FSH and $\mathrm{LH}$ increased $(P<0.01)$ within $24 \mathrm{~h}$ of unilateral ovariectomy (Fig. 1) followed by a 

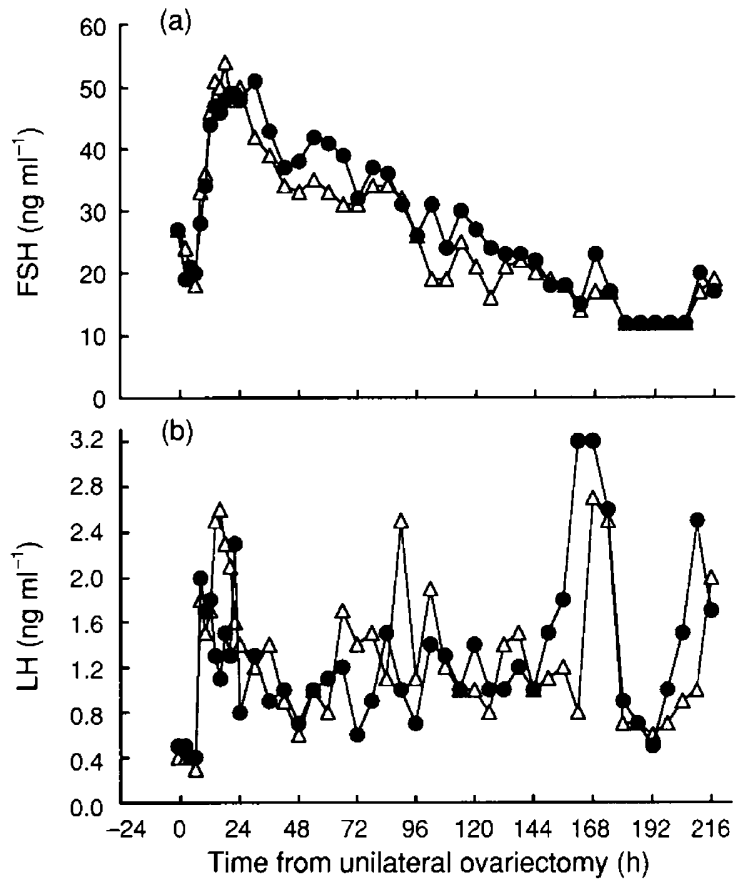

Fig. 1. Serum (a) FSH and (b) $\mathrm{LH}$ concentrations after unilateral ovariectomy of gilts immunized against human alpha globulins $(\Delta$; $n=5$ ) or bovine inhibin $\alpha{ }^{1-26} \mathrm{Gly}$-Tyr conjugated to human $\alpha$ globulins $(n=4)$. Standard errors for $\mathrm{LH}$ ranged from 0.1 to $2.1 \mathrm{ng} \mathrm{ml} \mathrm{m}^{-1}$, whereas standard errors for FSH ranged from 0 to $14.4 \mathrm{ng} \mathrm{ml}^{-1}$.

sustained increase $(P<0.01)$ in oestradiol (Fig. 2$)$ in control and bINH:HAG-immunized gilts. Serum concentrations of progesterone decreased after unilateral ovariectomy in both groups (Fig. 2). Serum LH, FSH, oestradiol and progesterone profiles did not differ between treatment groups after unilateral ovariectomy or when data were aligned based on day of oestrus after unilateral ovariectomy (data not shown).

\section{Antibody titres}

Antibody titres in bINH:HAG-treated gilts declined $(P<0.05)$ from $22 \pm 3 \%$ at week 17 before unilateral ovariectomy to $9 \pm 1 \%$ at week 23 when unilateral ovariectomy was carried out. In contrast, inhibin antibody titre was $0 \%$ in controls.

\section{Discussion}

The results presented in this study clearly show that active immunization of gilts against bINH:HAG blocks compensatory ovarian hypertrophy after unilateral ovariectomy without altering the patterns of gonadotrophin and ovarian steroid secretion or duration of the oestrous cycle compared with unilateral ovariectomy of controls immunized against HAG. In addition, the normal ovulation rate for a single ovary (in a gilt with both ovaries) was unaltered in bINH:HAG-immunized gilts, indicating that the negative effect of active immunization against bINH:HAG was specific to compensatory follicular growth and (a)
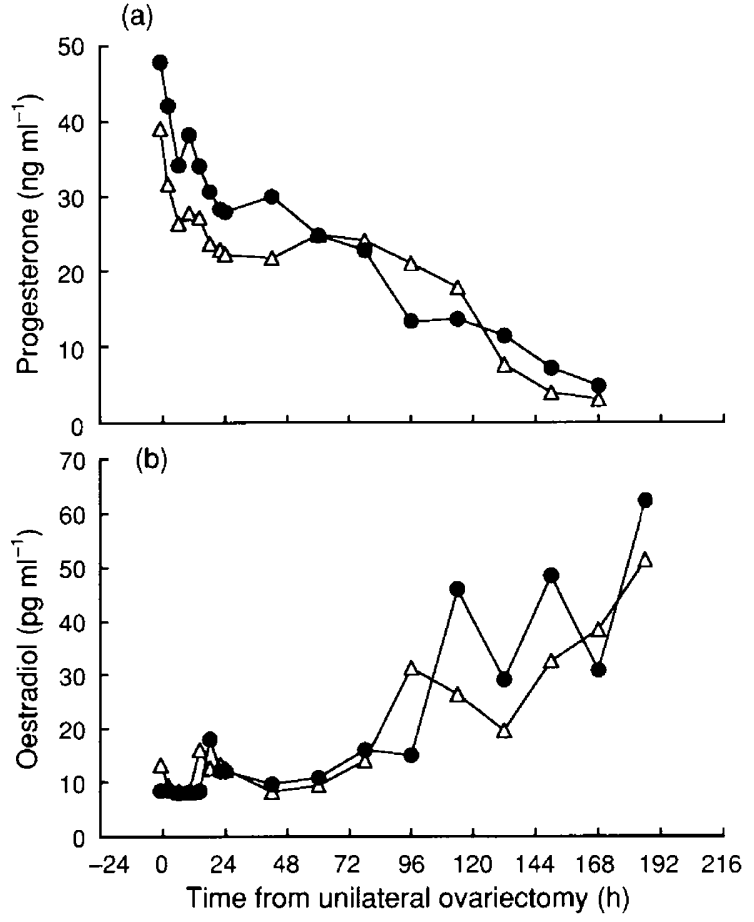

Fig. 2. Serum (a) oestradiol and (b) progesterone concentrations after unilateral ovariectomy of gilts immunized against human alpha globulins (HAG; $\triangle: n=5$ ) or bovine inhibin a ${ }^{1-26}$ Gly-Tyr conjugated to HAG $(n=4)$. Standard errors ranged from 1.3 to $17.8 \mathrm{pg}$ $\mathrm{ml}^{-1}$, for oestradiol and from 0.4 to $8.9 \mathrm{ng} \mathrm{ml}^{-1}$ for progesterone.

not the result of a general inhibitory effect of long-term immunoneutralization of inhibin or inhibin $\alpha$ subunits on follicular growth and function. These findings imply a specific, local, positive effect for inhibin or inhibin $\alpha$ subunits on compensatory follicular growth.

Nevertheless, the results of this unilateral ovariectomy study were surprising because a previous study (King et al., 1993), using the same gilts with both gonads, showed that active immunization against bINH:HAG increased the ovulation rate by $38 \%$ which was associated with transiently higher concentrations of FSH in the oestrous cycle before unilateral ovariectomy. In addition, injections of follicular fluid, which is rich in inhibins, block compensatory ovarian hypertrophy in gilts (Redmer et al., 1985). Thus, it was expected that active immunization against inhibin would have a positive effect on compensatory ovarian hypertrophy. Although the mechanism explaining how active immunization against bINH:HAG inhibits compensatory ovarian hypertrophy is not understood, results of several recent studies indicate a positive role for inhibin or inhibin $\alpha$ subunits in follicular growth and function. Specifically, ovarian mRNAs encoding inhibin increase in newly recruited follicles after unilateral ovariectomy of rats (D'Agostino et al., 1989) and during development of follicles in cattle (Ireland and Ireland, 1994). The immuno- and bio-activity of inhibin increases after unilateral ovariectomy of gilts and rats (Redmer et al., 1986; Ackland et al., 1990) and during follicular growth in cattle (Martin et al., 1991b; Ireland et al., 1994). Inhibin injected into an ovary enhances growth of medium-size follicles in rats (Woodruff et al., 1990) and stimulates androgen 
production by thecal cells of rats in vitro (Hillier et al., 1991). Inhibin $\alpha$ subunits bind the FSH receptor in rat granulosa cells (Schneyer et al., 1991) and may act as agonists to FSH, promoting follicular growth. On the basis of the results of the present study and others, we hypothesize that active immunization against bINH:HAG blocks the local stimulatory effects of inhibins or inhibin $\alpha$ subunits on the growth of a subpopulation of follicles that would normally undergo compensatory ovarian hypertrophy after unilateral ovariectomy of gilts.

While the reason FSH concentrations were not increased in gilts actively immunized against bINH:HAG in the present study, despite high titres of neutralizing inhibin antibodies (King et al, 1993), is unknown, other studies report similar results after active (Wrathall et al., 1990; Knight et al., 1991) or passive immunization (Mann et al, 1989) of sheep. In addition, our previous study (King et al., 1993) indicates a positive effect of actively immunizing gilts against bINH:HAG on FSH secretion and ovulation rate. Thus, the results of the present study appear paradoxical. Although the reason for these inconsistent results following active immunization against fragments of inhibin $\alpha$ subunits is unknown, there are numerous forms of inhibins and inhibin $\alpha$ subunits (Miyamoto et al., 1985, 1986; Sugino et al., 1992; Ireland et al., 1994) with different biological actions and potencies (Ghosh et al, 1994; Padmanabhan et al., 1994) in follicular fluid that are secreted into the peripheral circulation (Knight et al., 1989) in cattle. Thus, it is difficult to predict which forms of inhibin or inhibin $\alpha$ subunits in the peripheral circulation or follicular fluid are neutralized after active immunization against bINH:HAG, or whether the forms of inhibin or inhibin $\alpha$ subunits recognized by bINH:HAG antiserum change with decreasing titre and(or) time. Either, or both, of these possibilities could explain the different effects of active immunization against bINH:HAG on FSH secretion and ovulation rate in our previous (King ef al., 1993) compared with our present study. Alternatively, the different effects of active immunization against bINH:HAG on FSH secretion and ovulation rate may be unique to the two different animal models (intact versus unilateral ovariectomy) used in our studies.

Because compensatory ovarian hypertrophy was blocked after unilateral ovariectomy of gilts actively immunized against bINH:HAG, independent of alterations in serum concentrations of gonadotrophins or ovarian steroids, the duration of the oestrous cycle, or a reduction in the normal ovulation rate per ovary, we conclude that inhibins or inhibin a subunits act locally to stimulate positively compensatory ovarian hypertrophy in postpubertal gilts.

The authors acknowledge the technical assistance of $V$. Hedgpeth, T. Steffel, S. Wagner and T. Martin, and thank R. Fogwell and A. Tucker (Michigan State University, East Lansing, MI) for critique of this manuscript, G. D. Niswender (Colorado State University, Ft Collins, CO) for porcine LH antiserum, L. E. Reichert, Jr (Albany Medical College, Albany, NY) for purified LH, D. J. Bolt (USDAARS, Beltsville, MD) for purified FSH and FSH antiserum and N. R. Mason (Lily Research Labs, Indianapolis, IN) for oestradiol antiserum. The research was supported in part by USDA Grants 88-37240-4104 and 90-37240-5580 and Research Excellence Funds to J. J. Ireland and by grants from the NC Pork Producers Association to J. H. Britt.

\section{References}

Ackland JF, D'Agostino J, Ringstrom SJ, Hostetler JP, Mann BG and Schwartz NB (1990) Circulating radioimmunoassayable inhibin during periods of transient follicle-stimulating hormone rise: secondary surge and unilateral ovariectomy Biology of Reproduction 43 347-352

Armstrong JD and Britt JH (1987) Nutritionally-induced anestrus in gilts: metabolic and endocrine changes associated with cessation and resumption of estrous cycles Journal of Animal Science 65 508-523

Britt JH, Esbenshade KL and Zieck AJ (1991) Roles of estradiol and gonadotropin-releasing hormone in controlling negative feedback associated with luteinizing hormone in ovariectomized pigs Biology of Reproduction $\mathbf{4 5}$ $478-485$

Butcher RL (1977) Changes in gonadotropins and steroids associated with unilateral ovariectomy of the rat Endocrinology $101830-840$

Coleman DA, Fleming MW and Dailey RA (1984) Factors affecting ovarian compensation after unilateral ovariectomy in gilts Journal of Animal Science 59 170-176

Cox NM, Armstrong JD and Britt JH (1987) Influence of follicular ablation during lactation on postweaning interval to estrus, ovulation rate, and endocrine function in sows Domestic Animal Endocrinology 4 87-93

D'Agostino JB, Woodruff TK, Mayo KE and Schwartz NB (1989) Unilateral ovariectomy increases messenger ribonucleic acid levels in newly recruited follicles Endocrinology $124 \quad 310-317$

Esbenshade KL and Britt JH (1985) Active immunization of gilts against gonadotropin-releasing hormone: effects on secretion of gonadotropins, reproductive function and responses to agonist of gonadotropin-releasing hormone Biology of Reproduction 33 569-577

Ghosh BR, Ireland JJ, Good TEM, Ireland JLH, Padmanabhan V, Wu JC and Miller WL (1994) Inhibin variants have differential effects on GnRH-stimulated $\mathrm{Ca}^{++}$mobilization 76th Annual Meeting of the Endocrine Society, June 15-18, Anaheim, CA, Abstract 1642, p 611

Gill JL and Hafs HD (1971) Analysis of repeated measurements of animals Journal of Animal Science 33 331-336

Guthrie HD and Bolt DJ (1983) Changes in plasma estrogen, luteinizing hormone, follicle-stimulating hormone and 13,14-dihydro-15-ketoprostaglandin $\mathrm{F}_{2 u}$ during blockade of luteolysis in pigs after human chorionic gonadotropin treatment journal of Animal Science 57 993-1000

Hermreck AS and Greenwald GS (1964) The effects of unilateral ovariectomy on follicular maturation in the guinea pig Anatomical Record 148 171-176

Hillier SG, Yong EL, Illingworth PJ, Baird DT, Schwall RH and Mason AJ (1991) Effect of recombinant inhibin on androgen synthesis in cultured human thecal cells Molecular and Cellular Endocrinology 74 RI-R6

Howard HJ and Britt JH (1990) Prostaglandin $F_{2 u}$ causes regression of an hCG-induced corpus luteum before day 5 of its lifespan in cattle Journal of Reproduction and Fertility 90 245-253

Hunter J (1787) An experiment to determine the effect of extirpating one ovarium upon the number of young produced. Philosophical Transactions of the Royal Society of London Series B Biological Sciences 77 233-239

Ireland JLH and Ireland JJ (1994) Changes in expression of inhibin/activin $\alpha, \beta_{A}$ and $\beta_{B}$ subunit messenger ribonucleic acids following increases in size and during different stages of differentiation or atresia of non-ovulatory follicles in cows Biology of Reproduction 50 492-501

Ireland JLH, Good TEM, Knight PG and Ireland JJ (1994) Alterations in amounts of different forms of inhibin during follicular atresia Biology of Reproduction $50 \quad 1265-1276$

King BF, Britt JH, Esbenshade KL, Flowers WL, Sesti LAC, Martin TL and Ireland JJ (1993) Ovulatory and endocrine responses after active immunization of gilts against a synthetic fragment of bovine inhibin Journal of Animal Science $71975-982$

Knight PG, Beard AJ, Wrathall JHM and Castillo RJ (1989) Evidence that the bovine ovary secretes large amounts of monomeric inhibin alpha subunit and its isolation from bovine follicular fluid Journal of Molecular Endocrinology 2 189-200

Knight PG, Wrathall JHM, Glencross RG and McLeod BJ (1991) Effects of bovine follicular fluid on the secretion of $\mathrm{LH}$ and FSH in inhibin-immunized seasonally anoestrous ewes Journal of Endocrinology 128 403-410

Mann GE, Campbell BK, McNeilly AS and Baird DT (1989) Passively immunizing ewes against inhibin during the luteal phase of the oestrous cycle raises the plasma concentration of FSH Journal of Endocrinology 123 383-391. 
Martin TL, Williams GL, Lunstra DD and Ireland JJ (1991a) Immunoneutralization of inhibin modifies hormone secretion and sperm production in bulls Biology of Reproduction 45 73-77

Martin TL, Fogwell RL and Ireland JJ (1991b) Concentrations of inhibins and steroids in follicular fluid during development of dominant follicles in heifers Biology of Reproduction 44 693-700

Miyamoto K, Hasegawa Y, Fukuda M, Nomura M, Igarashi M, Kangawa K and Matsuo $H$ (1985) Isolation of porcine follicular fluid inhibin of $32 \mathrm{~K}$ Daltons Biochemical and Biophysical Research Communications 129 396-403

Miyamoto K, Hasegawa Y, Fukuda M and Igarashi M (1986) Demonstration of high molecular weight forms of inhibin in bovine follicular fluid (bFF) by using monoclonal antibodies to $32 \mathrm{~K}$ inhibin Biochemical and Biophysical Research Communications $1361103-1109$

NRC (1988) Nutrient Requirements of Swine (9th Edn). National Academy Press, Washington, DC

Padmanabhan V, Ireland JLH, Good TEM, McConnell DS, Midgley AR, Miller WL and Ireland JJ (1994) Evidence that molecular variants of bovine inhibin have differential endocrine and paracrine roles in modifying FSH secretion and action 76th Annual Meeting of the Endocrine Society, June 15-18, Anaheim, CA, Abstract 282, p 271

Redmer DA, Christenson RK, Ford JJ and Day BN (1984) Effect of unilateral ovariectomy on compensatory ovarian hypertrophy, peripheral concentrations of follicle-stimulating hormone and luteinizing hormone, and ovarian venous concentrations of estradiol-17 $\beta$ in prepubertal gilts Biology of Reproduction 31 59-66

Redmer DA, Christenson RK, Ford JJ and Day BN (1985) Effect of follicular fluid treatment on follicle-stimulating hormone, luteinizing hormone and compensatory ovarian hypertrophy in prepubertal gilts Biology of Reproduction 32 111-119
Redmer DA, Christenson RK, Ford JJ, Day BN and Goodman AL (1986) Inhibinlike activity in ovarian venous serum after unilateral ovariectomy in prepubertal gilts Biology of Reproduction 34 357-362

SAS (1985) SAS User's Guide: Statistics. SAS Ints., Inc., Cary, NC

Schneyer AL, Sluss PM, Whitcomb RW, Martin DA, Sprengel R and Crowley WF, Jr (1991) Precursors of alpha-inhibin modulate follicle-stimulating hormone receptor binding and biological activity Endocrinology 129 1987-1999

Short RE, Peters JB, First NL and Casida LE (1969) Effect of unilateral ovariectomy at three stages of the estrous cycle on the activity of the remaining ovary and pituitary gland Journal of Animal Science $27691-696$

Stevenson JS, Cox NM and Britt JH (1981) Role of the ovary in controlling luteinizing hormone, follicle-stimulating hormone and prolactin secretion during and after lactation in pigs Biology of Reproduction $\mathbf{2 4}$ 341-353

Sugino K, Nakamura T, Takio K, Miyamoto K, Hasegawa Y, Igarashi M, Titani K and Sugino $\mathbf{H}$ (1992) Purification and characterization of high molecular weight forms of inhibin from bovine follicular fluid Endocrinology 130 789-796

Welschen R, Dullaart J and de Jong FH (1978) Interrelationships between circulating levels of estradiol-17 $\beta$, progesterone, $\mathrm{FSH}$ and $\mathrm{LH}$ immediately after unilateral ovariectomy in the cyclic rat Biology of Reproduction 18 421-427

Woodruff TK, Lyon RJ, Hansen SE, Rice GC and Mather IP (1990) Inhibin and activin locally regulate rat ovarian follicunilateral ovariectomygenesis Endocrinology 127 3190-3205

Wrathall JHM, McLeod BJ, Glencross RG, Beard AJ and Knight PG (1990) Inhibin immunoneutralization by antibodies raised against synthetic peptide sequences of inhibin $\alpha$ subunit: effects on gonadotrophin concentrations and ovulation rate in sheep Journal of Endocrinology 124 167-176 